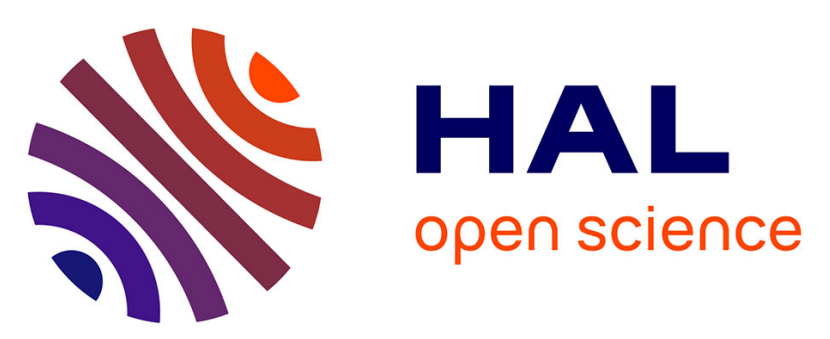

\title{
Phase transformation and amorphization upon alloys magnesiation: combining operando X-Ray diffraction and X-Ray Absorption Spectroscopy
}

Lucie Blondeau, Eddy Foy, Stéphanie Belin, Suzy Surblé, Fabienne Testard, Hicham Khodja, Magali Gauthier

\section{To cite this version:}

Lucie Blondeau, Eddy Foy, Stéphanie Belin, Suzy Surblé, Fabienne Testard, et al.. Phase transformation and amorphization upon alloys magnesiation: combining operando X-Ray diffraction and X-Ray Absorption Spectroscopy. 237th ECS Meeting, May 2020, Montréal, Canada. cea-02491929

HAL Id: cea-02491929

https://hal-cea.archives-ouvertes.fr/cea-02491929

Submitted on 26 Feb 2020

HAL is a multi-disciplinary open access archive for the deposit and dissemination of scientific research documents, whether they are published or not. The documents may come from teaching and research institutions in France or abroad, or from public or private research centers.
L'archive ouverte pluridisciplinaire HAL, est destinée au dépôt et à la diffusion de documents scientifiques de niveau recherche, publiés ou non, émanant des établissements d'enseignement et de recherche français ou étrangers, des laboratoires publics ou privés. 


\title{
Phase transformation and amorphization upon alloys magnesiation: combining operando X-Ray diffraction and X-Ray Absorption Spectroscopy
}

\author{
Lucie Blondeau ${ }^{1}$, Eddy Foy ${ }^{2}$, Stéphanie Belin ${ }^{3}$, Suzy Surblé ${ }^{1}$, Fabienne Testard ${ }^{4}$, Hicham Khodja ${ }^{1}$, Magali \\ Gauthier $^{1}$ \\ ${ }^{1}$ LEEL, NIMBE, CEA, CNRS, Université Paris-Saclay, CEA Saclay 91191 Gif-sur-Yvette France \\ ${ }^{2}$ LAPA-IRAMAT, NIMBE, CEA, CNRS, Université Paris-Saclay, CEA Saclay, 91191 Gif sur Yvette Cedex, France \\ ${ }^{3}$ Synchrotron SOLEIL, L’Orme des Merisiers, Saint-Aubin 91192 Gif-sur-Yvette, France \\ ${ }^{4}$ LIONS, NIMBE, CEA, CNRS, Université Paris-Saclay, CEA Saclay 91191 Gif-sur-Yvette France
}

e-mail: magali.gauthier@cea.fr

Magnesium appears as a great alternative to lithium due to its high capacity, low cost, abundance and largely smaller reactivity compared to lithium [1]. Magnesium metal has however a tendency to react with conventional electrolytes to form a barrier on its surface [1], impeding cations exchange, and thus dramatically limiting reversible stripping/deposition of $\mathrm{Mg}$. An interesting alternative is to replace $\mathrm{Mg}$ metal with negative electrode materials based on $p$-block elements (In, $\mathrm{Sn}, \mathrm{Sb}, \mathrm{Bi} . .$.$) as they electrochemically alloy with \mathrm{Mg}$ and possess adequate stability in standard electrolytes [2]. These substitute electrodes can thus prove a promising solution to overcome the problem of compatibility with electrolytes, even if the reaction mechanisms behind their operation in conventional electrolytes remain partly unsolved.

In a recent work, we investigated the electrochemical reactivity and performance of the InSb alloy as a negative electrode for Mg-ion batteries [3]. A strong synergy between $\mathrm{In}$ and $\mathrm{Sb}$ has been evidenced with the promotion of the electrochemical activity of $\mathrm{Sb}$ towards magnesiation/demagnesiation, in contrast to what was already reported for pure $\mathrm{Sb}$ electrodes where $\mathrm{Mg}^{2+}$ ions cannot be pulled out of the $\mathrm{Mg}_{3} \mathrm{Sb}_{2}$ phase after the first magnesiation [4].

Using complementary information from operando X-Ray diffraction (XRD) and X-Ray Absorption Spectrosopy (XAS), we further characterized in-depth the electrochemical behavior of InSb to understand its peculiar performance. Operando XRD measurements demonstrate the formation of the $\mathrm{Mg}_{3} \mathrm{Sb}_{2}$ phase almost all along the first magnesiation, accompanied by the extrusion of In metal. While crystalline MgIn has always been detected in the case of pure In or InBi electrodes [5], we observed a kinetically dependent electrochemically-driven amorphization of MgIn. This behavior suggests a possible competition between crystallization and amorphization in the material. EXAFS data, obtained at the In and $\mathrm{Sb} K$-edges at the ROCK beamline of synchrotron Soleil, corroborate the formation of $\mathrm{Mg}_{3} \mathrm{Sb}_{2}$ and $\mathrm{In}$ crystalline phases and the formation of MgIn, and give further insights on the atomic environement of In and Sb during the first magnesiation. Thanks to the evolution of EXAFS spectra as well as the changes in scattering paths, the phase proportions evolution as function of the number of $\mathrm{Mg}$ inserted into the alloy is followed (Figure 1).

These results shed light on synergetic effects between $p$-block elements for $\mathrm{Mg}$-ion batteries and more generally raise questions on the relation between in situ amorphization and electrochemical behavior.

\section{References:}

[1] Yoo et al., Energy Environ. Sci. 6, 2265-2279 (2013) 
[2] Zhang et al., Energy Storage Mater. 20, 118-38 (2019)

[3] Murgia et al., Electrochim. Acta, 259, 276- 283 (2018)

[4] Blondeau et al., Phys. Chem. C 123, 1120-1126 (2019)

[5] Murgia et al., Electrochim. Acta. 209, 730-736 (2016)

Figure 1: Evolution of the phase concentrations at the In and $\mathrm{Sb} K$-edges along the first magnesiation of a $\mathrm{InSb} / \mathrm{Mg}$ cell.

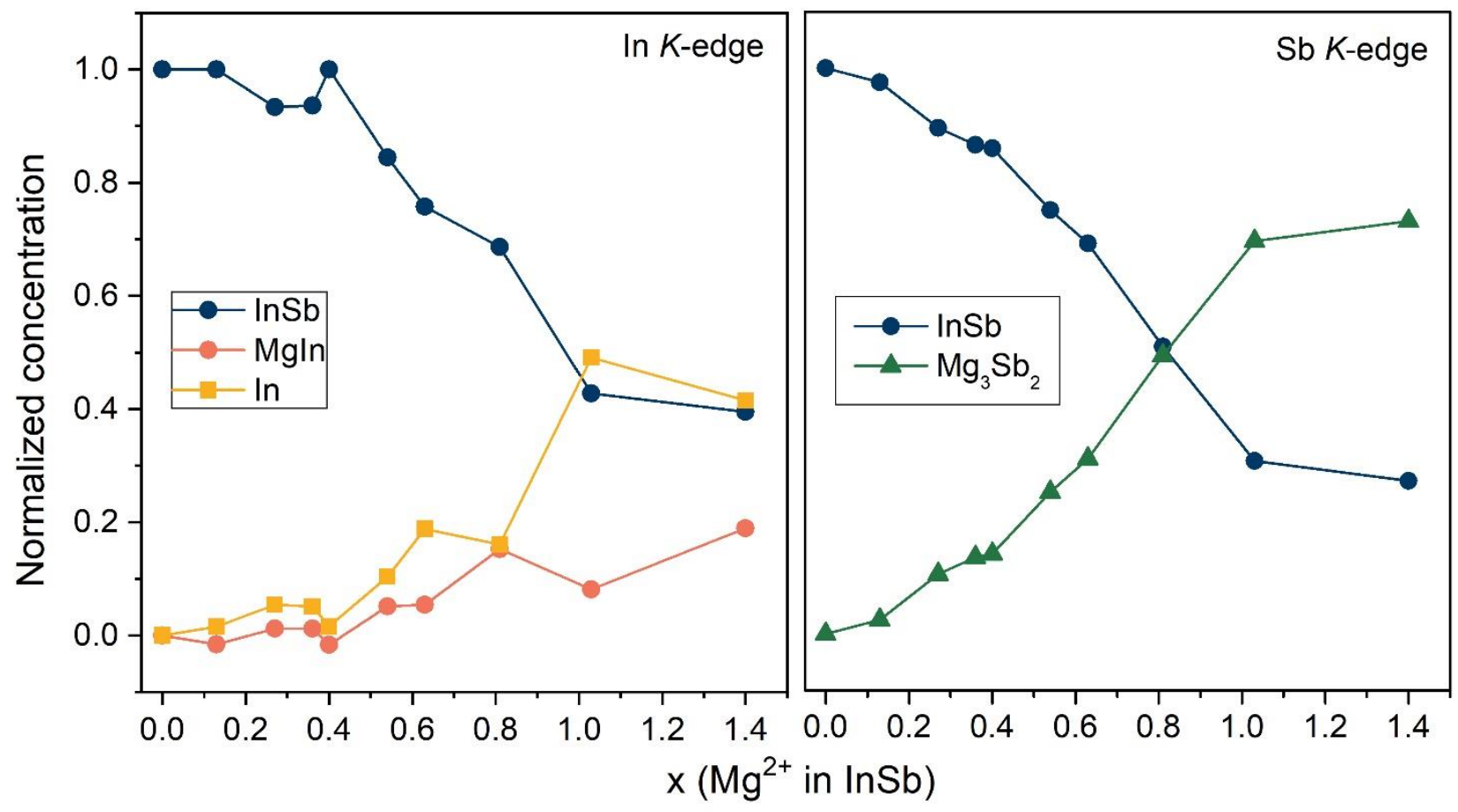

